\title{
KEMANDIRIAN DESA MELAWAN COVID-19 SECARA EKONOMI BERBASIS POTENSI DESA
}

\author{
Hani Sri Mulyani, Dadang Sudirno, Abdul Kholiq, Dede Salim Nahdi \\ Universitas Majalengka, Indonesia \\ hanisrimulyani@unma.co.id
}

\begin{abstract}
In handling the Covid-19 case, the Indonesian Government implemented several steps, including the imposition of Large-Scale Social Restrictions (PSBB) which led to the collapse of the national economy. In an effort to accelerate the handling of the Covid-19 case, the Majalengka Regency Government has issued various policies, from Determination of Emergency Alert Status to Enforcement of AKB. The PSBB policy implemented in Majalengka Regency has not been able to control the number of spread of COVID-19 cases. This can be seen from the number of COVID-19 cases which continue to grow every day. Temporary analysis that the awareness of the Majalengka community is generally still low due to lack of understanding and even indifference to the impact of the Corona virus. Majalengka University (UNMA), one of the universities in West Java province, is obliged to contribute to the prevention and handling of COVID-19 which is endemic in society. Through the Center for Research and Community Service (P3M), UNMA collaborates with the Task Force for the Acceleration of Handling COVID-19 in Majalengka Regency to carry out the Community Service Program (PPM) for lecturers and students.
\end{abstract}

Keywords: Village Independence, Covid-19, Economy, Village Potential

\begin{abstract}
Abstrak
Dalam menangani kasus Covid-19, Pemerintah Indonesia menrapkan beberapa langkah, diantaranya pemberakuan Pembatasan Sosial Bersekala Besar (PSBB) yang berujung pada jatuhnya perekonomian nasional. Dalam upaya percepatan penangan kasus Covid-19, Pemerintah Kabupaten Majalengka telah mengeluarkan berbagai kebijakan, dari mulai Penetapan Status Siaga Darurat sampai dengan Pemberlakuan AKB. Kebijakan PSBB yang dilaksanakan di Kabupaten Majalengka belum mampu mengendalikan jumlah penyebaran kasus COVID-19. Hal ini terlihat dari jumlah kasus COVID-19 yang terus bertambah setiap harinya. Analisis sementara bahwa kesadaran masyarakat Majalenka pada umumnya masih rendah diarenakan minimnya pahaman bahkan acuh terhadap dampak dari virus Corona. Universitas Majalengka (UNMA), salah satu perguruan tinggi yang ada di provinsi Jawa Barat berkewajiban untuk berkontribusi dalam pencegahan dan penanganan COVID-19 yang sedang mewabah di masyarakat. Melalui Pusat Penelitian dan Pengabdian Kepada Masyarakat (P3M) UNMA bekerjasama dengan Gugus Tugas Percepatan Penanganan COVID-19 Kabupaten Majalengka melaksanakan Program Pengabdian Masyarakat (PPM) dosen dan mahasiswa.
\end{abstract}

Kata Kunci: Kemandirian Desa, Covid-19, Ekonomi, Potensi Desa

Submitted: 2020-09-15 Revised: 2020-09-23 Accepted: $2020-09-24$

\section{Pendahuluan}

Pemerintah Indonesia mengkonfirmasi kasus COVID-19 pertama di Indonesia pada tanggal 2 Maret 2020 meskipun muncul beberapa spekulasi bahwa COVID-19 telah masuk ke Indonesia beberapa waktu sebelumnya (Tim detikcom, 2020). Per 14 Mei 2020, kasus positif COVID-19 sudah mencapai angka 16.006 dengan angka kesembuhan sebesar 3.518 dan kematian sebesar 1.043 jiwa (Idhom, 2020). Pemerintah Indonesia menerapkan beberapa langkah seperti menganjurkan warganya untuk tetap berada di 
rumah hingga pemberlakuan Pembatasan Sosial Berskala Besar atau disingkat PSBB, meskipun memang kebijakan tersebut menunjukkan adanya pembatasan kebebasan sipil masyarakat untuk berkumpul (Liputan6, 2020) serta adanya kemunduran dalam kinerja masyarakat dalam sektor ekonomi yang pada akhirnya berujung pada jatuhnya perekonomian pada skala nasional (Hadiwardoyo, 2020; Ansori, 2020; Ahmad, 2020), sehingga terdapat anjuran dari Ketua Gugus Tugas Percepatan Penanggulangan COVID19 dari BNPB yaitu Doni Monardo yang menyarankan bagi para warga dengan usia dibawah 45 tahun kebawah untuk diperbolehkan beraktivitas dengan tujuan untuk menggerakkan kembali perekonomian (Riana \& Amirullah, 2020).

Jumlah pasien COVID-19 yang terus meningkat tanpa terkendali menyebabkan Presiden memutuskan mengambil kebijakan Pembatasan Sosial Berskala Besar atau PSBB dalam menangani pandemi virus Corona atau COVID-19 di Tanah Air. Kebijakan tersebut diambil setelah pemerintah menilai penyakit ini merupakan penyakit yang dengan faktor risiko tinggi. Sebagai tindak lanjut atas kebijakan PSBB, maka beberapa arahan yang harus ditaati diantaranya 1) Kegiatan sekolah dan bekerja dilakukan di rumah; 2) Pembatasan kegiatan keagamaan; 3) pembatasan kegiatan di tempat/fasilitas umum; 4) Pembatasan kegiatan sosial dan budaya; 5) Pembatasan moda trasportasi; 6) Pembatasan kegiatan aspek lainnya khusus terkait aspek pertahanan dan keamanan. Kondisi perang melawan COVID-19 yang dialami saat ini menuntut masyarakat harus beraktivitas di rumah, menjaga jarak dengan orang lain dan menghindari kerumunan. Semua aktivitas dan komunikasi dilakukan secara online, tanpa harus keluar rumah. Hal ini dilakukan agar kita segera dapat menahan laju penyebaran yang terinfeksi virus Corona (COVID-19).

Dalam upaya percepatan penangan kasus Covid-19, Pemerintah Kabupaten Majalengka telah mengeluarkan berbagai kebijakan, diantaranya Penetapan Status Siaga Darurat, Penetapan Status Tanggap Darurat, Pembentukan Gugus Tugas, Pemberlakuakn PSBB, Perpanjangan PSBB, PSBB secara proposional dan perpanjangan PSBB, serta Pemberlakuan AKB.

Kebijakan PSBB yang dilaksanakan di Kabupaten Majalengka belum mampu mengendalikan jumlah penyebaran kasus COVID-19. Hal ini terlihat dari jumlah kasus COVID-19 yang terus bertambah setiap harinya. Analisis sementara bahwa masyarakat Majalenka pada umumnya masih belum paham bahkan acuh terhadap dampak dari virus Corona. Disisi lain tentunya ada faktor ekonomi yang menjadikan masyarakat terpaksa tetap beraktifitas di luar rumah. Melihat situasi ini, percepatan penganan COVID-19 harus dilakukan secara menyeluruh dan melibatkan semua pihak termasuk perguruan tinggi. Peran perguruan tinggi bisa dijadikan sebagai ujung tombak dalam peranannya untuk mensosialisasikan penanganan COVID-19 kepada masyarakat.

Pertumbuhan harian kasus suspek di Kabupaten Majalengka cukup fluktuatif selama masa sebelum PSBB sampai dengan pemberlakuan AKB. Dari data yag diperoleh dari Gugus Tugas Percepatan Penaggulangan Covid-19, kondisi saat ini Data Perkembangan Kasus Covid-19 di Kabupaten Majalengka per tanggal 3 Agustus 2020: 


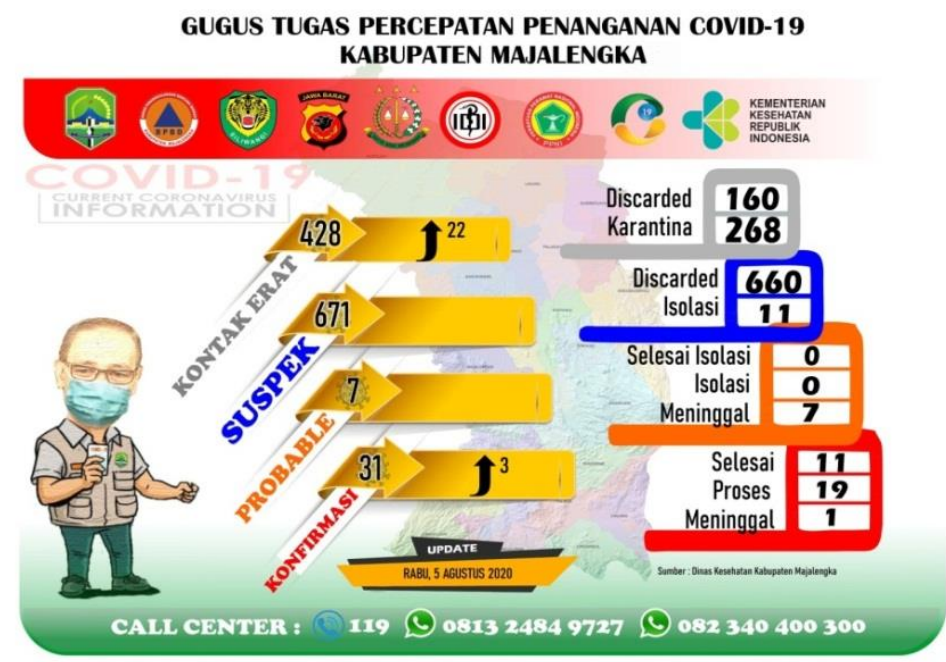

Gambar 1. Data Kontak, Suspek, Probabel dan Konfirmasi

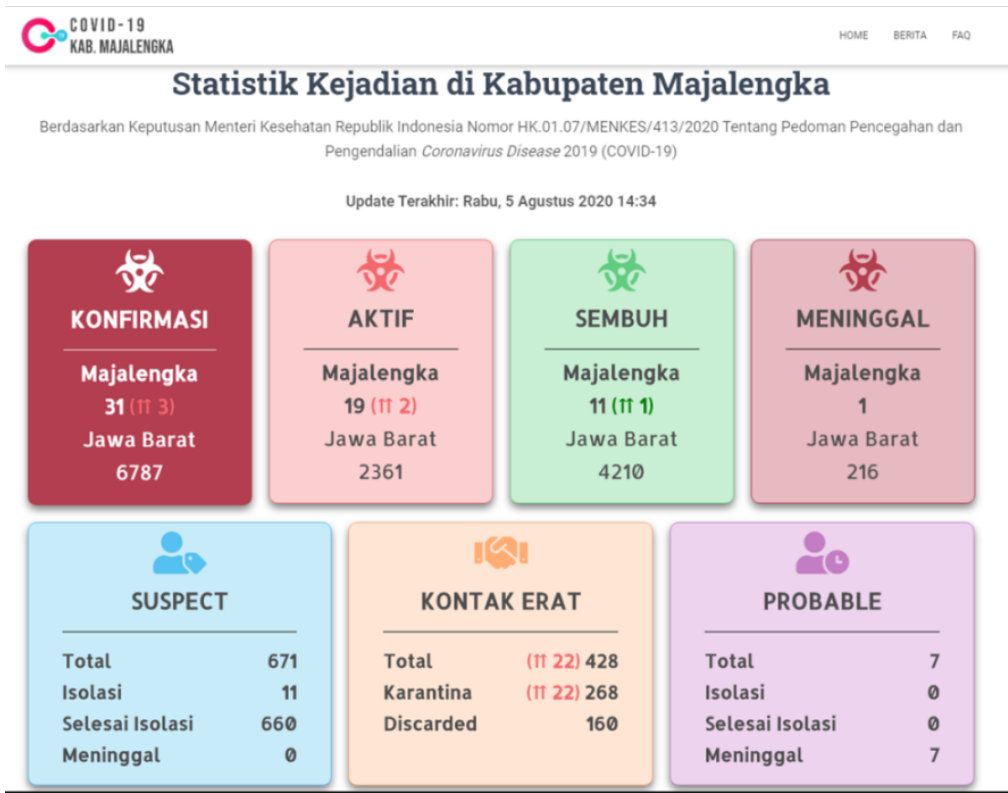

Gambar 2. Rincian Kasus Covid-19 di Kabupaten Majalengka

Universitas Majalengka (UNMA), salah satu perguruan tinggi yang ada di provinsi Jawa Barat berkewajiban untuk berkontribusi dalam pencegahan dan penanganan COVID19 yang sedang mewabah di masyarakat. Melalui Pusat Penelitian dan Pengabdian Kepada Masyarakat (P3M) UNMA bekerjasama dengan Gugus Tugas Percepatan Penanggulangan COVID-19 melaksanakan Program Pengabdian Masyarakat (PPM) yang dilakukan oleh dosen dan mahasiswa secara interdisipliner, institusional, dan kemitraan sebagai salah satu wujud dari tridharma perguruan tinggi. Program pengabdian kepada masyarakat sebagai program yang wajib dilaksanakan, baik oleh dosen maupun oleh mahasiswa, dengan berlandaskan pada prinsip-prinsip: (1) kompetensi akademik; (2) kewirausahaan; dan professional; sehingga dapat menghasilkan program pengabdian kepada masyarakat yang bermutu, relevan, dan sinergis dalam meningkatkan pemberdayaan masyarakat (Ruyadi dkk, 2010:172). 


\section{METODE PELAKSANAAN}

1. Program yang Disepakati Bersama Antara Tim PPM dengan Pemdes

PPM dilaksanakan dari tanggal 12 sampai dengan tanggal 29 Agustus 2020 dengan mengambil loksi di desa Maja Utara Kecamatan Maja Kabupaten Majalengka. Penetapan lokasi tersebut berdasarkan hasil koordinasi dengan Gugus Tugas Percepatan Penanggulangan COVID-19 Kabupaten Majalengka. Desa Maja Utara, berdasarkan hasil evaluasi Gugus Tugas Covid, termasuk salah satu desa di Kabupaten Majalengka yang aman dari kasus pandemi Covid-19 (Zona Hijau).

Sasaran dari PPM adalah masyarakat desa Maja Utara Kecamatan Maja. Tim PPM Universitas Majalengka terdiri dari 4 orang dosen pembimbing dan melibatkan 16 mahasiswa dari berbagai fakultas yang ada di Universitas Majalengka.

Melalui diskusi dan koordinasi antara tim PPM dengan pemerintah desa, menyepakati bahwa kegiatan PPM adalah mendukung dan menguatkan program penanggulangan dan pencegahan pandemik Ccovid-19 yang sedang dan sudah dilakukan oleh pemerintah pusat dan pemerintah daerah (Tabel 1). Program-program tersebut akan dilaksanakan secara kolaboratif melalui sosialisasi, edukasi, praktek langsung, monitoring dan evaluasi.

Tabel 1. Permasalahan, Solusi dan Target Luaran, Indikator Capaian

\begin{tabular}{|c|c|c|c|c|}
\hline No. & Permasalahan & Program & Target Luaran & $\begin{array}{l}\text { Indikator } \\
\text { Capaian }\end{array}$ \\
\hline 1. & $\begin{array}{l}\text { Kurangnya } \\
\text { dukungan } \\
\text { masyarakat } \\
\text { terhadap } \\
\text { penguatan } \\
\text { program } \\
\text { penanggulangan } \\
\text { dan pencegahan } \\
\text { Covid-19 yang } \\
\text { dilakukan } \\
\text { Pemerintah } \\
\text { Pusata dan } \\
\text { Daerah. }\end{array}$ & $\begin{array}{l}\text { Memberikan Pehaman } \\
\text { kepada masyarakat tentang } \\
\text { Pandemi Covid-19 melalui: } \\
\text { 1. Edukasi dan sosilaisasi } \\
\text { tentang pencegahan } \\
\text { Covid-19 bagi anak } \\
\text { Sekolah (TK/PAUD s/d } \\
\text { SMA/SMK/Pondok } \\
\text { Pesantren) } \\
\text { 2. Edukasi dan sosialisasi } \\
\text { tentang pencegahan } \\
\text { Covid-19 bagi } \\
\text { masyarakat } \\
\text { 3. Penyemprotan } \\
\text { disinfectan. } \\
\text { 4. Pendampingan } \\
\text { pembuatan Contactless } \\
\text { Hand sanitizer }\end{array}$ & $\begin{array}{l}\text { 1. Terlaksananya } \\
\text { dukungan dan } \\
\text { penguatan } \\
\text { program } \\
\text { penanggulangan } \\
\text { dan pencegahan } \\
\text { Covid-19 yang } \\
\text { dilakukan } \\
\text { Pemerintah Pusat } \\
\text { dan Pemerintah } \\
\text { Daerah Kabupaten } \\
\text { Majalengka. } \\
\text { 2. Meningkatnya } \\
\text { pemahaman dan } \\
\text { kesadaran } \\
\text { masyarakat } \\
\text { tentang bahaya } \\
\text { dan cara } \\
\text { pencegahan Covid- } \\
19\end{array}$ & $\begin{array}{l}\text { 1. Bertambahny } \\
\text { a masyarakat } \\
\text { yang } \\
\text { menggunaka } \\
\mathrm{n} \text { masker } \\
\text { saat } \\
\text { beraktifitas; } \\
\text { 2. Tersedianya } \\
\text { alat cuci } \\
\text { tangan di } \\
\text { tempat- } \\
\text { tempat } \\
\text { umum. } \\
\text { 3. Adanya } \\
\text { poster/gamb } \\
\text { ar di tempat- } \\
\text { tempat } \\
\text { tertentu } \\
\text { tentang } \\
\text { bahaya dan } \\
\text { pencegahan } \\
\text { Covid-19 }\end{array}$ \\
\hline 2. & $\begin{array}{l}\text { Menurunnya } \\
\text { kondisi } \\
\text { perekonomian di } \\
\text { desa akibat } \\
\text { Pandemik Covid- } \\
19\end{array}$ & $\begin{array}{l}\text { Pendampingan } \\
\text { Pemanfaatan e-commerce } \\
\text { bagi pelaku UMKM }\end{array}$ & $\begin{array}{l}\text { Para pelaku UMKM } \\
\text { dapat } \\
\text { mengembangkan } \\
\text { pemasaran secara } \\
\text { digital }\end{array}$ & $\begin{array}{l}\text { Para pelaku } \\
\text { UMKM dapat } \\
\text { mempromosik } \\
\text { an produk } \\
\text { secara online }\end{array}$ \\
\hline 2. & $\begin{array}{l}\text { Belum adanya } \\
\text { data tentang }\end{array}$ & $\begin{array}{l}\text { Pendataan ekonomi } \\
\text { masyarakat yang }\end{array}$ & $\begin{array}{l}\text { Tersedianya data } \\
\text { tentang: }\end{array}$ & $\begin{array}{l}\text { Pemdes } \\
\text { mempunyai }\end{array}$ \\
\hline
\end{tabular}




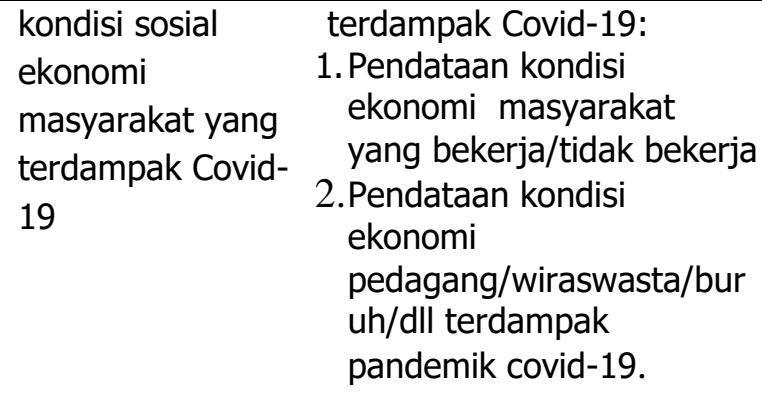

\begin{tabular}{|c|c|}
\hline $\begin{array}{l}\text { 1. Kondisi ekonomi } \\
\text { masyarakat yang } \\
\text { bekerja/tidak } \\
\text { bekerja } \\
\text { 2. Kondisi ekonomi } \\
\text { pedagang/wiraswa } \\
\text { sta/buruh yang } \\
\text { terdampak } \\
\text { 485andemic covid- } \\
\text { 19. }\end{array}$ & $\begin{array}{l}\text { data tentang: } \\
\text { 1. Kondisi } \\
\text { ekonomi } \\
\text { masyarakat } \\
\text { yang } \\
\text { bekerja/tidak } \\
\text { bekerja } \\
\text { 2. Kondisi } \\
\text { ekonomi } \\
\text { pedagang/wi } \\
\text { raswasta/bur } \\
\text { uh yang } \\
\text { terdampak } \\
\text { 485andemic } \\
\text { covid-19. }\end{array}$ \\
\hline
\end{tabular}

2. Metode Pelaksanaan PPM

Metode PPM yang dilaksanakan untuk menyelesaikan persoalan di Desa Maja Utara dengan program yang telah disepakati bersama adalah sebagai berikut :

1) Tahap Persiapan

Pada tahap persiapan, langkah-langkah yang dilakukan adalah :

a. Informasi dan sosialisasi internal kampus kepada mahasiswa, berkenaan dengan pelaksanaan Program Pngabdian Masyarakat .

f. Koordinasi dengan Pemerintahan Kabupaten Majalengka, Gugus Tugas Penanganan Cocid-19, Badan Penanggulangan Bencana Daerah Kabupaten Majalengka, Dinas Kesehatan serta Dinas/Lembaga lain yang memiliki atau menyelenggarakan program Pemberdayaan Masyarakat.

g. Observasi ke lokasi untuk menyiapkan pemondokan, (bila diperlukan dan kondisional), survey awal dan pengkondisian terhadap Camat, Kepala Desa dan masyarakat setempat.

j. Menyusun pra program.

k. Pembagian tugas Tim.

I. Penyiapan atribut, perbekalan, akomodasi dan transportasi.

m. Persiapan pemberangkatan.

2) Tahap Pelaksanaan

Pelaksanaan PPM yang dilakukan adalah sebagai berikut :

a. Mengidentifikasi sasaran program.

b. Melakukan koordinasi dengan RT/RW/Desa/Kelurahan, guru/kepala sekolah/lembaga terkait untuk pencegahan Pandemik Covid-19

c. Menyiapkan dan melaksanakan program pendataan/pencarian data.

d. Menyiapkan materi, metoda, media sesuai dengan program yang akan dilaksanakan.

f. Merintis dan mengembangkan jaringan kemitraan kepada lembaga terkait untuk pencegahan Covid-19.

g. Membuat publikasi pelaksanaan /hasil kegiatan PPM pandemik Covid-19.

h. Melakukan jaringan kerja sama dengan pengelola media massa elektronik dan cetak.

i. Mengevaluasi Kegiatan. 
3) Tahap Monitoring dan Evaluasi

a. Monev dirancang sedikitnya 2 kali menjelang akhir KNM (minggu tengah - akhir);

b. Monev awal difokuskan untuk melihat kesesuaian perencanaan dengan kondisi lokasi, sehingga diperoleh umpan balik untuk perbaikan program.

c. Monev menjelang akhir program difokuskan untuk mempertajam pelaksanaan program agar dapat efektif dan pembahasan persiapan seminar hasil untuk mengevaluasi tingkat keberhasilan dan program tindak lanjut.

4) Tahap Pelaporan

Penyusunan laporan keseluruhan oleh tim pelaksana.

\section{Hasil dan Pembahasan}

1. Penguatan pehaman Masyarakat tentang Pandemi Covid-19

a) Sapa Warga dan Edukasi Pencegahan Covid-19

Memberikan arahan tentang protokol kesehatan yang harus dilaksanakan oleh seluruh masyarakat seperti tidak menyentuh mulut, mata juga hidung serta tidak berkerumun ditempat ramai, cuci tangan sesering mungkin dengan menggunakan/memakai hand sanitizer, selalu menggunakan masker saat keluar rumah dan mengganti masker setiap hari. Selain itu, selalu diusahakan untuk selalu menjaga jarak.

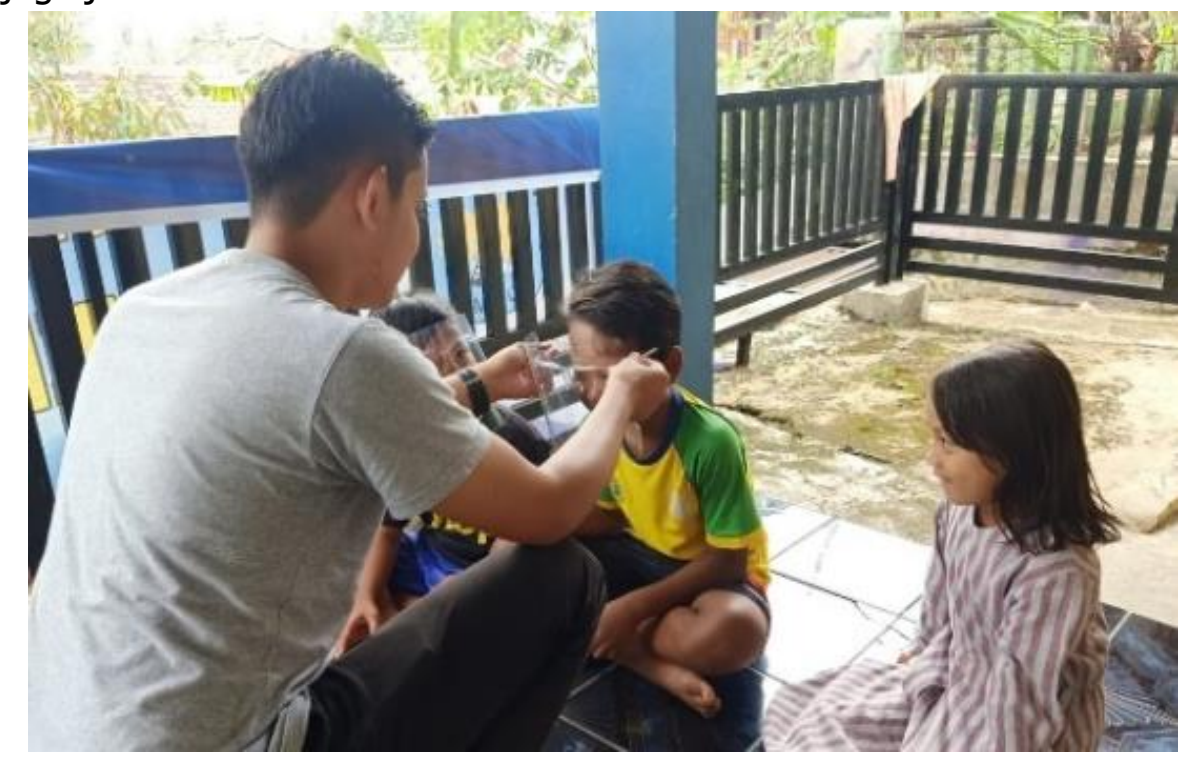

Gambar 3. Sapa Warga dan Edukasi Pencegahan Covid-19

b) Pembuatan Media Edukasi Pencegahan Covid-19

Di dalam pembuatan media luring berupa video yang berisikan tentang pencegahan Covid-19 serta cara pencegahannya, mulai dari cara cuci tangan dengan air mengalir menggunakan sabun/hand sanitizer, cara pakai masker yang baik, selalu menjaga jarak, serta penerapan adaptasi kebiasaan baru (AKB). Media luring berupa vieo ini dibuat untuk diterapkan dalam kehidupan masyarakat seharhari. Proses pembuatannya dimulai dari konsep, pengambilan gambar, editing, sampai video siap tayang. 


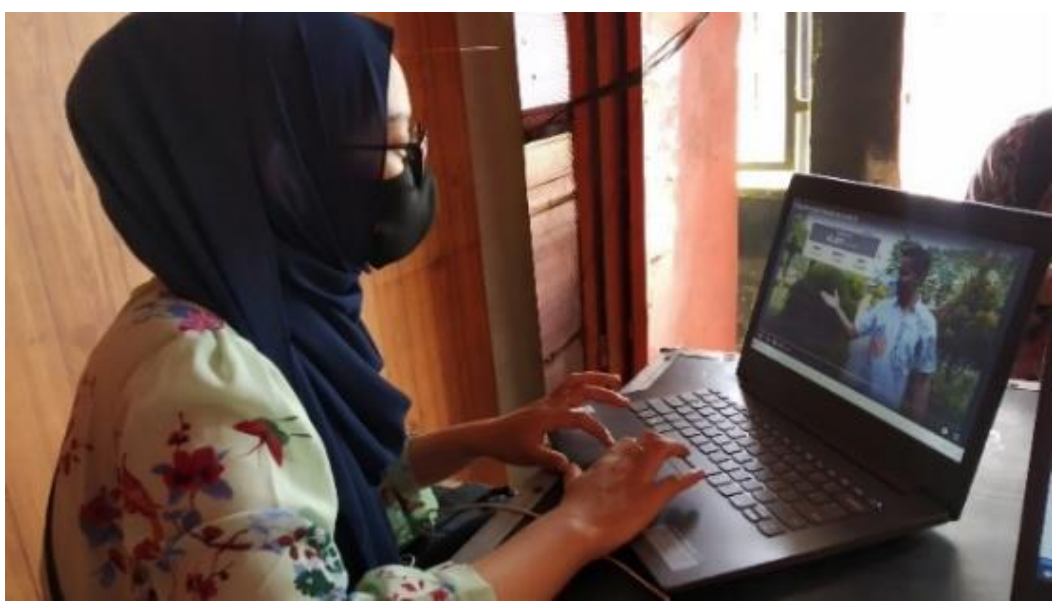

Gambar 4. Pembuatan Video Edukasi

c) Penyemprotan Disinfectan

Penyemprotan disinfectan dilaksanakan pada tanggal 25 - 27 Agustus 2020 di Blok Kamis dan Blok Jumat Desa Maja Utara oleh tim PPM didampingi oleh aparat desa. Objek penyemprotan dilakukan pada tempat-tempat umum, seperti mushola, mesjid, pondok peantren, dan sekolah.

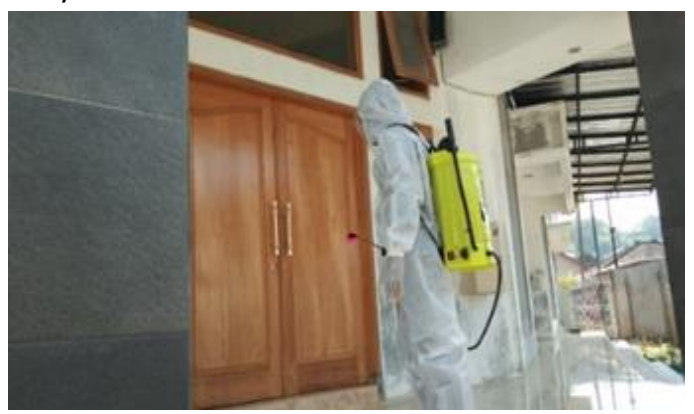

Gambar 5. Penyemprotan Disinfectan

d) Pendampingan Pembuatan Contactless Hand Sanitizer

Contactless Hand Sanitizer adalah Hand Sanitizer yang dilengkapi sensor sehingga cairan akan keluar sendiri ketika tangan didekatkan. Memudahkan pengguna tanpa menekan atau menyentuhnya dan mengurangi kontak langsung. Alat pembuatannya terdiri dari water pump (pompa air), sensor E18-D80NK (sensor jarak).

Pembuatan Contactless Hand Sanitizer dilakukan di kantor Pemerintahan Desa Maja Utara selama kurang lebih satu minggu. Mulai dari penyiapan alat dan bahan, perakitan sampai Contacless Hand Sanitizer siap digunakan.

Dengan adanya projek percontohan dengan metode pendampingan pembuatan Contacless Hand Sanitizer, diharapkan seluruh masyarakat bisa membuat sendiri sehingga setiap rumah atau minimal diperkantoran atau diskolah-sekolah mempunyai alat tesebut untuk lebih memudahkan ketika cuci tangan. 

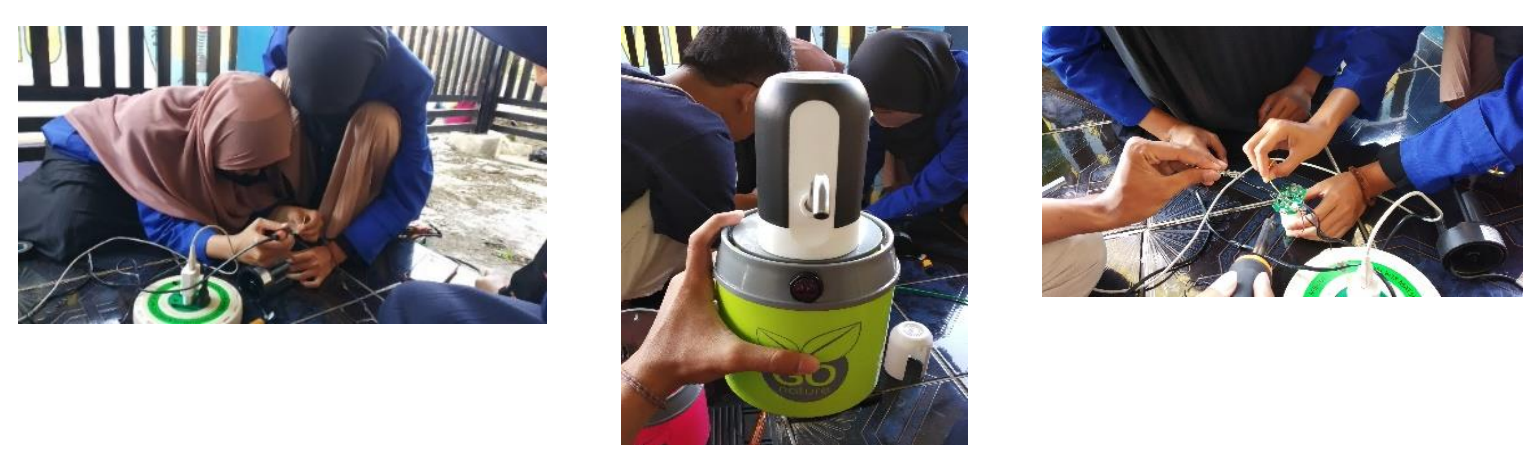

Gambar 6. Proses Pembuatan/Perakitan Contacless Hand Sanitizer

e) Edukasi Pencegahan Vovid-19

Kegiatan edukasi dilaksanakan di SD Maja Utara 1 tanggal 24 Agustus 2020. proses pembelajaran dilakukan secara luring/tatap muka, siswa belajar di bagi menjadi beberapa kelompok. Kelompok 1 belajar pada hari senin, rabu dan Jum'at sedangkan kelompok 2 belajar pada hari Selasa, Kamis dan Sabtu.

Tim PPM memberikan sosialisasi dan edukasi kepada siswa Sekolah Dasar mengenai pencegahan Covid-19 serta menampilkan video yang menarik serta penerapan Adaptasi Kebiasaan Baru (AKB).

Kegiatan edukasi pada anak-anak TK/PAUD dilaksanakan di TK Az-zahra pada tanggal 24-25 Agustus 2020. Dengan dibantu oleh para guru dalam proses pembelajaran mulai dari mengaji iqro, edukasi pencegahan COVID-19 diiringi dengan lagu yang menarik sehingga anak-anak PAUD tidak jenuh dalam menyimak edukasi pencegahan COVID-19.

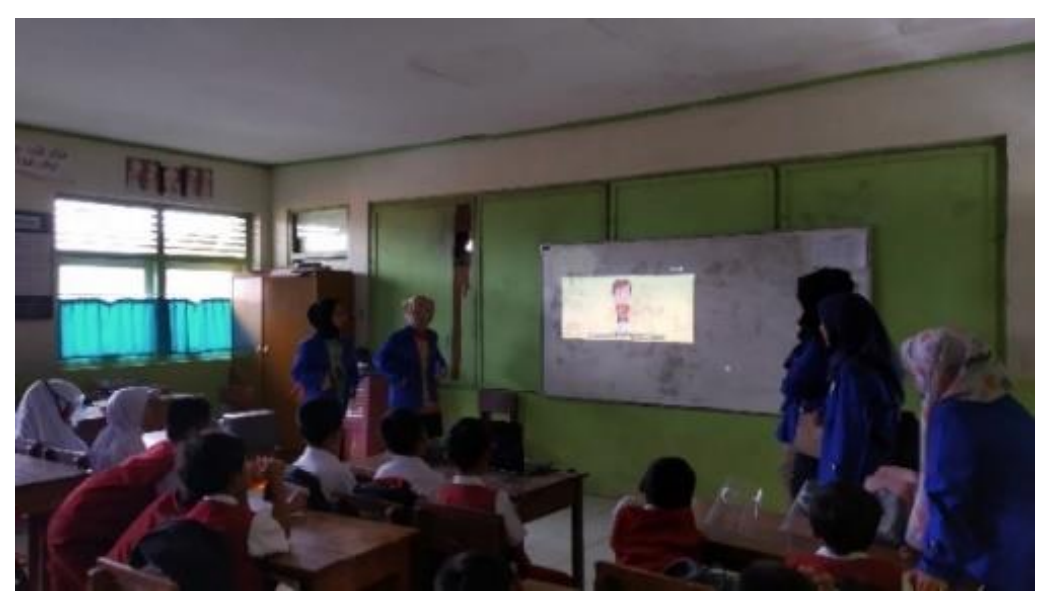

Gambar 7. Edukasi Pencegahan Covid-19

2. Pendampingan Pemanfaatan Media Sosial Bagi Pelaku UMKM

Dalam persaingan perdagangan yang semakin ketat dan semakin berkembangnya dunia digital menuntut untuk semua pedagang mampu memanfaatkan media social untuk mampu bersaing dalam pemasaran produk. Sehingga perlu dilakukan sosialisasi dan pendampingan secara langsung turun lapang untuk mengajarkan para pemilik UMKM dalam penggunaan media social sebagai tempat pemsaran produk secara luas. 
Semakin berkembangnya dunia digital banyak produsen yang beralih ke penjualan secara online yang perlu diterapkan di desa Maja Utara agar tidak tertingal dalam hal pemasaran.
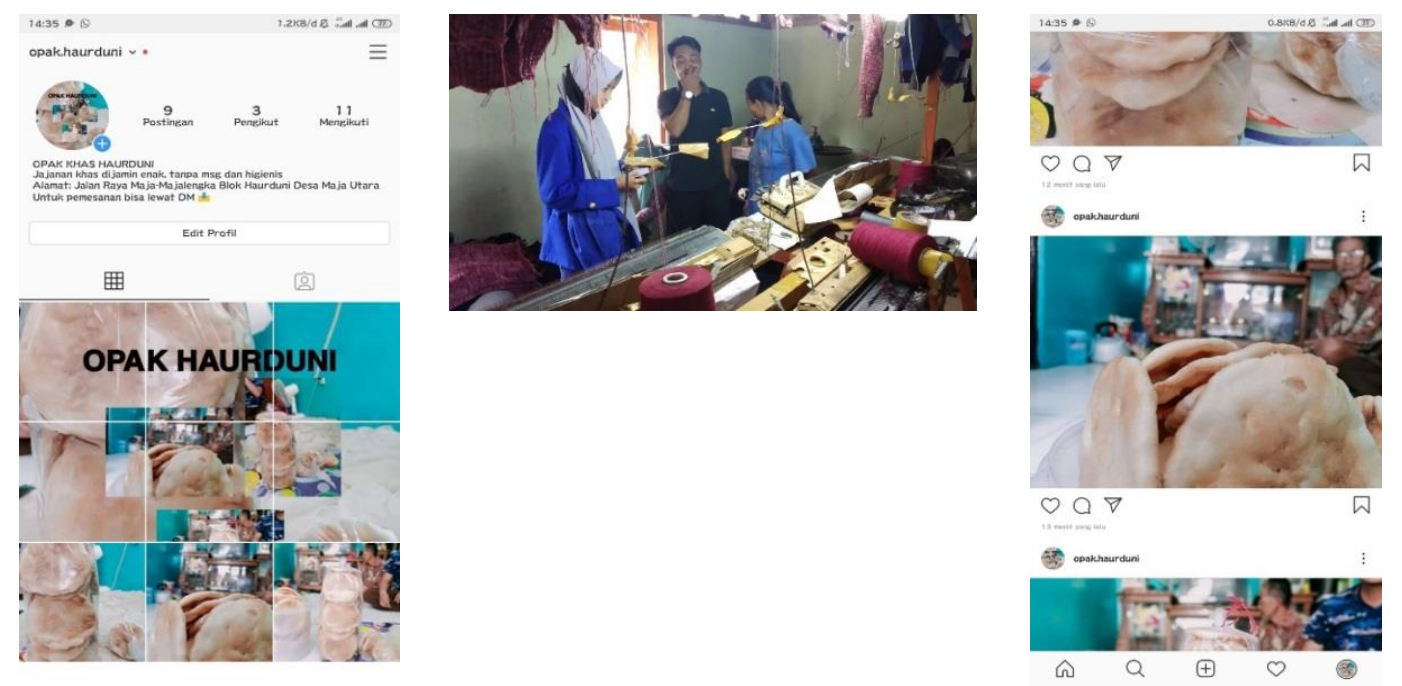

@ $\quad \oplus \quad$ 웅

Gambar 8. Pendampingan Pemanfaatan Media Sosial

3. Pendataan Kondisi Ekonomi Masyarakat yang Terdampak Covid-19

Program ini dimaksudkan untuk membantu pemutakhiran data yang dibutuhkan di dalam upaya pencegahan Covid-19. Dalam pelaksanaannya, Tim PPM melakukan kerja sama dengan RT/RW/Dusun/Desa. Adapun pendataan yang dilakukan di antaranya yaitu pendataan jumlah penduduk menurut usia, tingkat pendidikan, dan pekerjaan, pendataan penduduk yang masuk dan keluar wilayah, pendataan kondisi ekonomi pedagang/wiraswasta/sopir/dan lain-lain yang terdampak pandemik Covid-19 dan pendataan penduduk yang secara ekonomi tidak mampu.

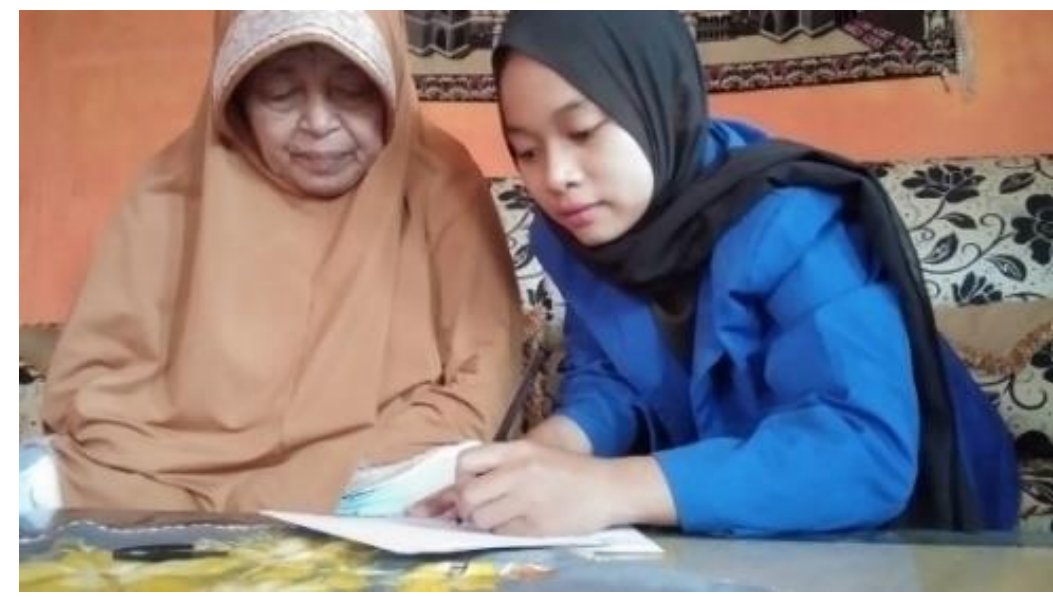

Gambar 9. Pendataan Kondisi Ekonomi Masyarakat

\section{Kesimpulan}

Secara umum kegiatan Program Pengabdian Masyarakat dosen dan mahasiswa Universitas Majalengka di Desa Maja Utara Kecamatan Maja Kabupaten Majalengka yang 
dilaksanakan dari tanggal 12 - 29 Agustus 2020 berjalan dengan baik dan lancar sesuai dengan rencana yang sudah ditetapkan sebelumnya. Masyarakat yang terlibat, dengan semangat dan antusias mengikuti semua kegiatan yang dilaksanakan oleh tim PPM, begitu juga pihak Pemerintah Desa sangat mendukung dan banyak membantu sehingga PPM dapat berjalan sesuai dengan apa yang diharapkan.

Setiap kegiatan selalu menerapkan dengan disiplin protokol kesehatan sesuai yang disarankan oleh Gugus Tugas Covid-19. Pada akhir kegiatan, Tim PPM menyumbangkan 2 unit Contacless Hand Sanitizer . satu untuk digunakan di Kantor Pemerintahan Desa dan satu unit untuk digunakan di Kantor Kecamatan.

Berdasarkan hasil monitoring dan evaluasi, sebagian besar masyarakat sudah dapat memahami dan sadar tentang bahaya Covid-19 dengan bertambahnya kedisiplinan dalam menerapkan protokol kesehatan, seperti semakin banyak masyarakat yang selalu menggunakan masker, tempat cuci tangan semakin bertambah terutam di tempat-tempat umum dan selalu menjaga jarak pada ketika beraktifitas.

\section{Daftar Pustaka}

Al Fatta, Hanif. (2007). Analisis dan Perancangan Sistem Informasi Untuk Keunggulan Bersaing Perusahaan dan Organisasi Modern. Yogyakarta: Andi Offset.

Arief M. Rudyanto. (2011). Pemrograman Web Dinamis menggunakan PHP dan MySQL. Yogyakarta: Andi Ofset.

Arbie. (2004). Manajemen Database dengan MySQL. Yogyakarta: Andi Offset.

Jogiyanto, HM. (2005). Analisis dan Desain Sistem Informasi: Pendekatan Terstruktur Teori dan Praktek Aplikasi Bisnis. Yogyakarta: Andi Offset.

Gugus Tugas Percepatan Penangan Covid-19 RI (2020), Kumpulan Peraturan-Perturan Mengenai Penganan Covid-19 di Desa .

Kessa, Wahyudin. (2015). Perencanaan Pembangunan Desa. Kementerian Desa, Pembangunan Daerah Tertinggal, Dan Transmigrasi Republik Indonesia. Jakarta.

Kurniawan, Boni. (2015). Desa Mandiri, Desa Membangun. Kementerian Desa, Pembangunan Daerah Tertinggal, dan Transmigrasi Republik Indonesia. Jakarta.

Kusrini. (2007). Strategi Perancangan dan Pengelolaan Basis Data. Yogyakarta: Andi Offset.

Pusat Penelitian dan Pengabdian Masyarakat Universitas Majalengka, (2020). Panduan Kerja Nyata Mahasiswa Tahun 2020.

Pemerintahan Desa Maja Utara. (2019). Buku Potensi Desa Maja Utara.

Sholeh, Chabib. (2014). Dialektika Pembangunan Dengan Pemberdayaan. Bandung: Fokusmedia.

Widjaja, HAW. (2003). Pemerintahan Desa/Marga. PT. Raja Grafindo Persada. Jakarta.

www.detik.com, 2020

www.kompas.com, 2020 